\title{
Geophysical mapping of palsa peatland permafrost
}

\author{
Y. Sjöberg ${ }^{1}$, P. Marklund ${ }^{2}$, R. Pettersson ${ }^{2}$, and S. W. Lyon ${ }^{1}$ \\ ${ }^{1}$ Department of Physical Geography and the Bolin Centre for Climate Research, Stockholm University, Stockholm, Sweden \\ ${ }^{2}$ Department of Earth Sciences, Uppsala University, Uppsala, Sweden
}

Correspondence to: Y. Sjöberg (ylva.sjoberg@natgeo.su.se)

Received: 15 August 2014 - Published in The Cryosphere Discuss.: 13 October 2014

Revised: 3 February 2015 - Accepted: 10 February 2015 - Published: 4 March 2015

\begin{abstract}
Permafrost peatlands are hydrological and biogeochemical hotspots in the discontinuous permafrost zone. Non-intrusive geophysical methods offer a possibility to map current permafrost spatial distributions in these environments. In this study, we estimate the depths to the permafrost table and base across a peatland in northern Sweden, using ground penetrating radar and electrical resistivity tomography. Seasonal thaw frost tables (at $\sim 0.5 \mathrm{~m}$ depth), taliks (2.1-6.7 $\mathrm{m}$ deep), and the permafrost base (at $\sim 16 \mathrm{~m}$ depth) could be detected. Higher occurrences of taliks were discovered at locations with a lower relative height of permafrost landforms, which is indicative of lower ground ice content at these locations. These results highlight the added value of combining geophysical techniques for assessing spatial distributions of permafrost within the rapidly changing sporadic permafrost zone. For example, based on a back-ofthe-envelope calculation for the site considered here, we estimated that the permafrost could thaw completely within the next 3 centuries. Thus there is a clear need to benchmark current permafrost distributions and characteristics, particularly in under studied regions of the pan-Arctic.
\end{abstract}

\section{Introduction}

Permafrost peatlands are widespread across the Arctic and cover approximately $12 \%$ of the arctic permafrost zone (Hugelius et al., 2013; Hugelius et al., 2014). They often occur in sporadic permafrost areas, protected by the peat cover, which insulates the ground from heat during the summer (Woo, 2012). In the sporadic permafrost zone, the permafrost ground temperature is often close to $0{ }^{\circ} \mathrm{C}$, and therefore even small increases in temperature can result in thawing of permafrost. In addition, permafrost distribution and thaw- ing in these landscapes are influenced by several factors other than climate, including hydrological, geological, morphological, and erosional processes that often combine in complex interactions (e.g., McKenzie and Voss, 2013; Painter et al., 2013; Zuidhoff, 2002). Due to these interactions, peatlands are often dynamic with regards to their thermal structures and extent, as the distribution of permafrost landforms (such as dome-shaped palsas and flat-topped peat plateaus) and talik landforms (such as hollows, fens, and lakes) vary with climatic and local conditions (e.g., Sannel and Kuhry, 2011; Seppälä, 2011; Wramner, 1968). This dynamic nature and variable spatial extent has potential implications across the pan-Arctic as these permafrost peatlands store large amounts of soil organic carbon (Hugelius et al., 2014; Tarnocai et al., 2009). The combination of large carbon storage and high potential for thawing make permafrost peatlands biogeochemical hotspots in the warming Arctic. In light of this, predictions of future changes in these environments require knowledge of current permafrost distributions and characteristics, which is sparse in today's scientific literature.

While most observations of permafrost to date consist of temperature measurements from boreholes, advances in geophysical methods provide a good complement for mapping permafrost distributions in space. Such techniques can provide information about permafrost thickness and the extent and distribution of taliks, which can usually not be obtained from borehole data alone. As the spatial distribution and extent of permafrost directly influences the flow of water through the terrestrial landscape (Sjöberg et al., 2013), adding knowledge about the extent and coverage of permafrost could substantially benefit development of coupled hydrological and carbon transport models in northern latitudes (e.g., Jantze et al., 2013; Lyon et al., 2010). This may be particularly important for regions where palsa peat- 
lands make up a large portion of the landscape mosaic and regional-scale differences exist in carbon fluxes (Giesler et al., 2014).

Geophysical methods offer non-intrusive techniques for measuring physical properties of geological materials; however, useful interpretation of geophysical data requires other types of complementary data, such as sediment cores. Ground penetrating radar (GPR) has been used extensively in permafrost studies for identifying the boundaries of permafrost (e.g., Arcone et al., 1998; Doolittle et al., 1992; Hinkel et al., 2001; Moorman et al., 2003), characterizing ground ice structures (De Pascale et al., 2008; Hinkel et al., 2001; Moorman et al., 2003), and estimating seasonal thaw depth and moisture content of the active layer (Gacitua et al., 2012; Westermann et al., 2010). Electrical resistivity tomography (ERT) has also been widely applied in permafrost studies (Hauck et al., 2003; Ishikawa et al., 2001; Kneisel et al., 2000 ), the majority of which focus on mountain permafrost. By combining two or more geophysical methods complementary information can often be acquired raising the confidence in interpretations of permafrost characteristics (De Pascale et al., 2008; Hauck et al., 2004; Schwamborn et al., 2002). For example, De Pascale et al. (2008) used GPR and capacitive-coupled resistivity to map ground ice in continuous permafrost and demonstrated the added value of combining radar and electrical resistivity measurements for the quality of interpretation of the data. While some non-intrusive geophysical investigations have been done in palsa peatland regions (Dobinski, 2010; Doolittle et al., 1992; Kneisel et al., 2007, 2014; Lewkowicz et al., 2011), the use of multiple geophysical techniques to characterize the extent of permafrost in palsa peatland environments has not been employed.

In this study we use GPR and ERT in concert to map the distribution of permafrost along three transects (160 to $320 \mathrm{~m}$ long) in the Tavvavuoma palsa peatland in northern Sweden. Our aim is to understand how depths of the permafrost table and base vary in the landscape and, based on resulting estimates of permafrost thickness, to make a first-order assessment of the potential time needed to completely thaw this permafrost due to climate warming. Furthermore, we hope to demonstrate the added value of employing complementary geophysical techniques in such landscapes. This novel investigation thus helps contribute to our understanding of the current permafrost distribution and characteristics across palsa peatlands, creating a baseline for future studies of possible coupled changes in hydrology and permafrost distribution in such areas.

\section{Study area}

Tavvavuoma is a large palsa peatland complex in northern Sweden at $68^{\circ} 28^{\prime} \mathrm{N}, 20^{\circ} 54^{\prime} \mathrm{E}, 550 \mathrm{~m}$ a.s.l. (Fig. 1) and consists of a patchwork of palsas, peat plateaus, thermokarst lakes, hummocks, and fens. Ground temperatures and

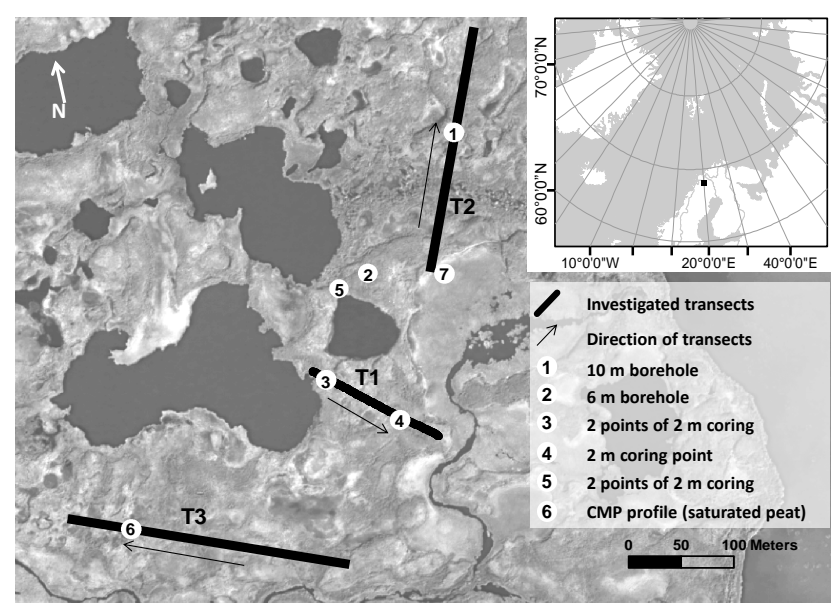

Figure 1. Location of the study site (inset), investigated transects, existing boreholes (Ivanova et al., 2011, points 1 and 2), coring points, and point of CMP measurement (described in Sect. 3.1; aerial photograph from Lantmäteriet, the Swedish land survey, 2012).

weather parameters have been monitored at the site since 2005 (Christiansen et al., 2010). Sannel and Kuhry (2011) have analyzed lake changes in the area and detailed local studies of palsa morphology have been conducted by Wramner $(1968,1973)$.

Tavvavuoma is located on a flat valley bottom, in piedmont terrain with relative elevations of surrounding mountains about 50 to $150 \mathrm{~m}$ above the valley bottom. Unconsolidated sediments, observed from two borehole cores (points 1 and 2 in Fig. 1), are of mainly glaciofluvial and lacustrine origin and composed of mostly sands, loams, and coarser-grained rounded gravel and pebbles (Ivanova et al., 2011). The mean annual air temperature is $-3.5^{\circ} \mathrm{C}$ (Sannel and Kuhry, 2011), and the average winter snow cover in Karesuando, a meteorological station approximately $60 \mathrm{~km}$ east of Tavvavuoma, is approximately $50 \mathrm{~cm}$, although wind drift generally gives a thinner snow cover in Tavvavuoma (Swedish Meteorological and Hydrological Institute, http://www.smhi.se/klimatdata/ meteorologi).

Permafrost occurs primarily under palsas and peat plateaus in Tavvavuoma, where the average thickness of the active layer is typically $0.5 \mathrm{~m}$ (Christiansen et al., 2010; Sannel and Kuhry, 2011). The mean annual temperature in permafrost boreholes is $2^{\circ} \mathrm{C}$ (Christiansen et al., 2010). However, no observations of the depth to the permafrost base have been presented for the area. Warming of the air temperature of about $2{ }^{\circ} \mathrm{C}$ has been observed in direct measurements from the region over the past 200 years (Klingbjer and Moberg, 2003). In light of this warming, winter precipitation (mainly snow) in northern Sweden shows increasing trends over the past 150 years (Alexandersson, 2002). Furthermore, permafrost is degrading across the region and northern Sweden (Sjöberg et al., 2013). For example, peatland active layer thickness 
in Abisko (located about $60 \mathrm{~km}$ southwest of Tavvavuoma) is increasing according to direct observation over the past 30 years (Akerman and Johansson, 2008) and inference from hydrologic shifts over the past century (Lyon et al., 2009). This regional permafrost degradation has led to changes in palsas as well. Regionally, reductions in both areas covered by palsas and palsa height have been observed (Sollid and Sorbel, 1998; Zuidhoff, 2002; Zuidhoff and Kolstrup, 2000). In Tavvavuoma, both growth and degradation of palsas have been observed in detailed morphological studies during the 1960s and 1970s (Wramner, 1968, 1973), and expansion and infilling of thermokarstic lakes have been observed through remote sensing analyses (Sannel and Kuhry, 2011). Palsa degradation and infilling of lakes with fen vegetation have been the dominating processes during recent years (Sannel and Kuhry, 2011; Wramner et al., 2012).

\section{Theory and methods}

Measurements of permafrost extent and structure were made with both GPR and ERT between 20 and 26 August 2012 along three transects covering the main permafrost landforms in the Tavvavuoma area (Fig. 1). The ERT transects were somewhat extended (i.e., slightly longer) compared to the GPR transects to increase the penetration depth along the overlapping parts of the transects.

Transect T1 was $160 \mathrm{~m}$ long and crossed a peat plateau that was raised approximately $1.5 \mathrm{~m}$ above the surrounding landscape (Fig. 1). It further crossed two thermokarst depressions (centered at 45 and $130 \mathrm{~m}$ ) within the peat plateau. Transect T2 was $320 \mathrm{~m}$ long, but the southern part covering about $180 \mathrm{~m}$ could not be measured with GPR due to dense vegetation cover (mainly Salix sp.). Transect T2 started on a peat plateau surface at the edge of a drained lake and continued north over a fen (110-180 m) and a small stream $(140 \mathrm{~m})$. The northern part, measured with both ERT and GPR, crossed a palsa $(200 \mathrm{~m})$ that was raised about $4 \mathrm{~m}$ above the surrounding landscape. This palsa has been described via a borehole profile (Ivanova et al., 2011; point 1 in Fig. 1). Transect T2 then continued across two fens (250 and $290 \mathrm{~m}$ ) separated by a lower palsa $(270 \mathrm{~m})$. Transect T3 was $275 \mathrm{~m}$ long. It started on a relatively low palsa and stretched over a flat area covered by hummocks and thermokarst depressions.

In addition to the geophysical investigations (details of which are described in the following sections), the depth to the permafrost table (the active layer) was probed every $2 \mathrm{~m}$ along all transects using a $1 \mathrm{~m}$ steel rod. Sediment cores were retrieved at four points along $\mathrm{T} 1$ and two points along T3 down to $2 \mathrm{~m}$. These cores were used to locate the depth to the peat-mineral substrate interface and the depth to the permafrost table (at points 3, 4, 5, and 6 in Fig. 1). The topography was measured along the transects using a differential GPS with supplemental inclinometer observations along profiles where only ERT was used. The position of the transects was measured using a tape measure and marked at regular intervals to ensure that locations of GPR and ERT transects coincided.

\subsection{Ground penetrating radar}

Ground penetrating radar (GPR) can be used to map near surface geology and stratigraphy because of differences in dielectric properties between different subsurface layers or structures. An electromagnetic pulse is transmitted through the ground and the return time of the reflected pulse is recorded. The resolution and penetration depth of the radar signal depends on the characteristics of the transmitted pulse and the choice of antennas, which usually range between 10 and $1000 \mathrm{MHz}$. Higher frequencies will yield a higher resolution but a smaller penetration depth; however, the penetration depth will also depend on dielectric and conductive properties of the ground material. Mapping of permafrost using GPR becomes possible due to the difference in permittivity between unfrozen and frozen water.

In this study, measurements were made with a Malå GeoScience ProEx GPR system using $200 \mathrm{MHz}$ unshielded antennas along $\mathrm{T} 1$ and $\mathrm{T} 2$. The transmitting and receiving antennas were held at a constant distance of $0.6 \mathrm{~m}$ (common offset) and the sampling time window was set to $621 \mathrm{~ns}$, with recorded traces stacked 16 times. Measurements were made at every $10 \mathrm{~cm}$ along the length of these two transects. Along T3, measurements were made using $100 \mathrm{MHz}$ unshielded antennas with a $1 \mathrm{~m}$ antenna separation and measurements made every $0.2 \mathrm{~s}$ while moving the antennas along the transect. The sampling time window for T3 was $797 \mathrm{~ns}$ and traces were stacked 16 times. The GPR data were processed for a time-zero correction and with a dewow filter, a vertical gain, and a normal-moveout correction for antenna geometry using the software ReflexW (version 6.1, Sandmeier Geophysical Research, 2012, http://www.sandmeier-geo.de).

The depths to the permafrost table and the interface between peat and mineral substrates were calculated by converting the two-way travel time to known substrate transitions using estimated velocities for the speed through three different substrate materials: dry peat, saturated peat, and saturated mineral substrate (see Fig. 2 for conceptual sketch of these substrate layers and velocity profiles). To account for uncertainty due to small-scale heterogeneity of these ground materials, in addition to the optimal "representative" velocity identified, the likely maximum and minimum velocities for each substrate were considered in the GPR depth conversions (Table 1). The end product here is a range of plausible substrate velocities accounting for potential uncertainties such that any resultant interpretation about subsurface conditions and interface locations can be considered robust. The velocity in dry peat (found in the active layer of palsas, hummocks, and peat plateaus) was calibrated using the active layer thickness measurements made with a steel rod. The minimum and maximum velocities were obtained by subtracting and 
Table 1. Velocities used for converting two-way travel times to depth in GPR data.

\begin{tabular}{lcl}
\hline Material & $\begin{array}{c}\text { Velocity } \\
\left(\mathrm{m} \mathrm{ns}^{-1}\right)\end{array}$ & Method/source \\
\hline Dry peat - representative & 0.049 & Calibration against every second field measurements* of active layer depths \\
Dry peat - min & 0.046 & Representative estimate minus 1 standard deviation of field measurements* \\
Dry peat - max & 0.052 & Representative estimate plus 1 standard deviation of field measurements* \\
Saturated peat - representative & 0.036 & Calibration against coring (points 3 and 5, in Fig. 1) \\
Saturated peat - min & 0.033 & Velocity in pure water (Davis and Annan, 1989) \\
Saturated peat - max & 0.049 & Representative estimate for dry peat \\
Saturated mineral - representative & 0.060 & Velocity in sand and clay from Davis and Annan (1989) \\
Saturated mineral - min & 0.053 & Calculated from Joseph et al. (2010) for saturated loams and sands \\
Saturated mineral - max & 0.073 & Highest estimated velocity from CMP analysis \\
\hline
\end{tabular}

* Field measurement using a $1 \mathrm{~m}$ steel rod.

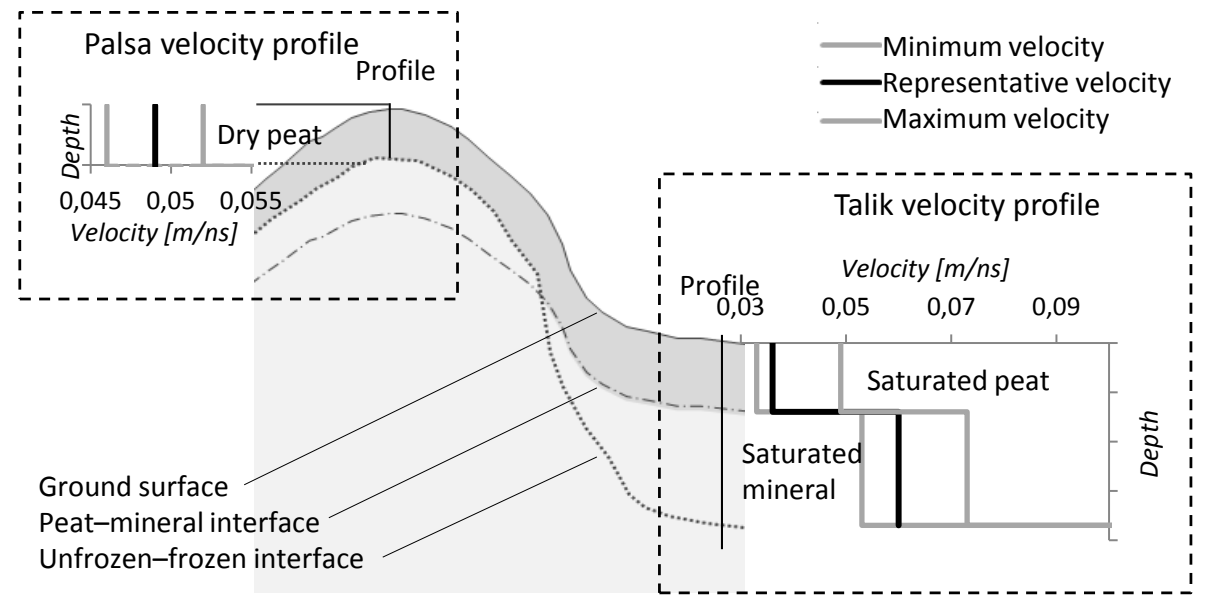

Figure 2. Conceptual sketch of typical distribution of ground substrates and associated estimated velocities for a palsa and talik ground profile.

adding 1 standard deviation of the measured depths, respectively. For velocities in saturated peat that was found in taliks such as fens, the thickness of the saturated peat layer identified by coring with a $2 \mathrm{~m}$ steel pipe (points 3 and 5, Fig. 1) was used. The velocity in pure water was used as the minimum velocity and the representative velocity for dry peat was used as the maximum velocity for saturated peat.

To obtain velocities for unfrozen saturated mineral substrate, a common midpoint (CMP) GPR profile was measured on a drained lake surface (point 7 in Fig. 1). Coring down to $2 \mathrm{~m}$ with a steel pipe at this location revealed the existence of an unfrozen saturated peat layer down to 1.75 $m$ depth and unfrozen mineral soils consisting of mainly sand and silt below that depth. CMP analysis is a widely used method to estimate local GPR signal velocities through ground materials. By moving GPR transmitting and receiving antennas apart incrementally between measurements, the same point in space is imaged with different antenna offsets, making it possible to back out material velocity estimates from the hyperbolic shape of the recorded reflectors.
The measured reflectors must be relatively flat so that the signal moves through the same materials at the same depths independent of antenna offset. For the CMP measurement, $100 \mathrm{MHz}$ unshielded antennas were moved apart in $10 \mathrm{~cm}$ increments along a $15 \mathrm{~m}$ transect with a time window of $797 \mathrm{~ns}$ and 16 stacks of each trace. The data were processed in ReflexW software (version 6.1, Sandmeier Geophysical Research, 2012, http://www.sandmeier-geo.de) for a time-zero correction, a dewow filter, and a vertical gain. Semblance analysis (Neidell and Tanner, 1971) was used to identify appropriate reflectors from which velocities could be estimated. Figure 3 shows the estimated velocity profile, recorded CMP radargram, and semblance plot for the CMP transect. Although a relatively flat reflector was identified for the CMP measurement, the results from the semblance analysis does not show one clear reflector and associated velocity at the identified depth of the peat-mineral interface. Instead, a wide range of possible velocities are shown in the semblance plot for the top $\sim 200 \mathrm{~ns}$, likely due to high heterogeneity in ground substrates and/or water content. Due to the difficulty 


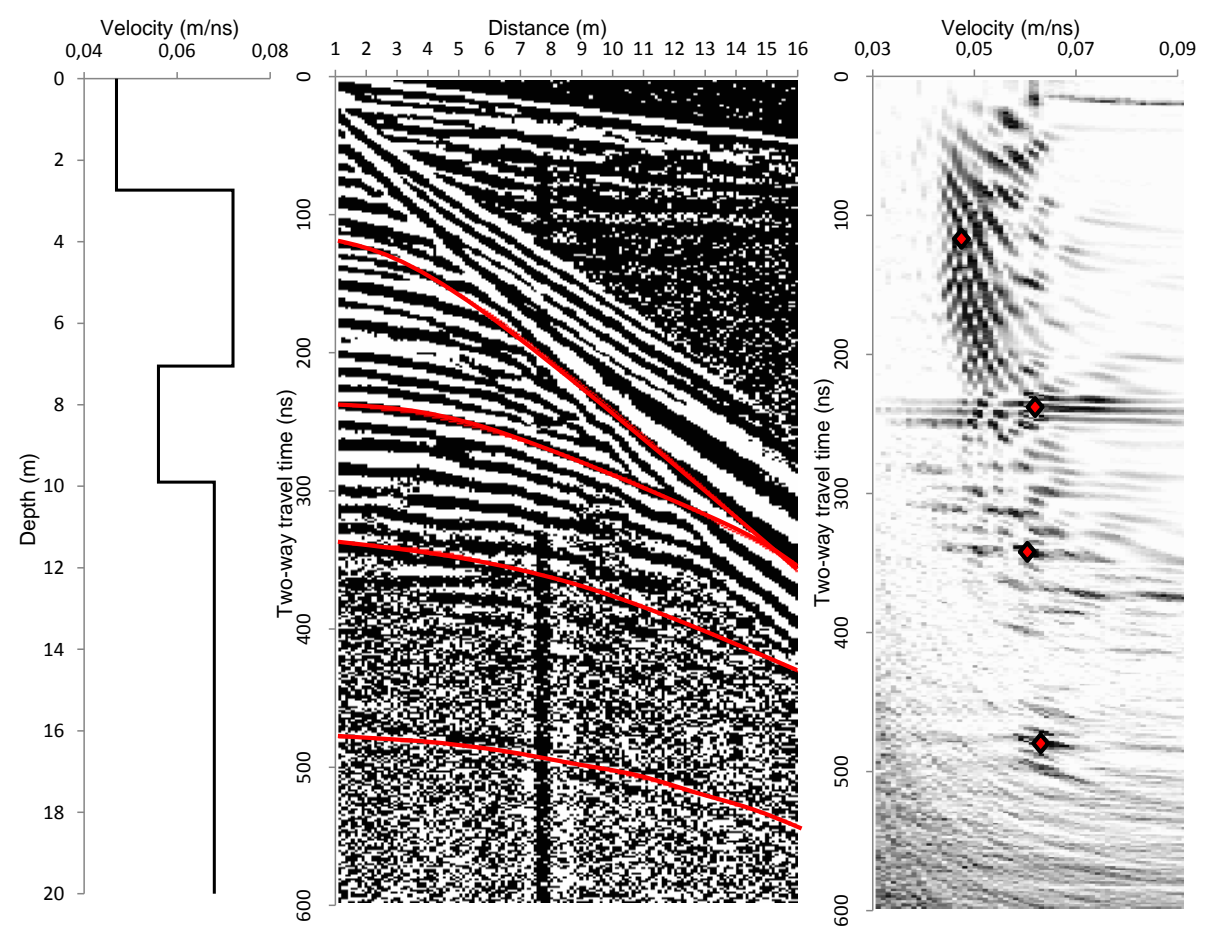

Figure 3. Estimated velocity profile, recorded CMP radargram, and semblance plot for the CMP transect measured on the drained lake surface. The semblance plot shows more likely velocities in darker shades of grey with the velocities from the reflectors (red lines in radargram) used for generating the velocity profile indicated by black and red diamonds.

in constraining the material velocities for the deeper layers using this method, these results were only used for estimating a probable maximum velocity in unfrozen mineral sediments (as this was higher than most literature values). This maximum velocity estimate was complemented with literature values for the representative and minimum velocities.

\subsection{Electrical resistivity tomography}

Direct-current electrical resistivity measurements are based on a measured potential difference between two electrodes $(\Delta V)$ inserted with galvanic coupling to the ground and, similarly, two electrodes where current is injected into the ground $(I)$ with a known geometric factor $(k)$ depending on the arrangement of the electrodes. This gives a value of the apparent resistivity $\left(\rho_{\mathrm{a}}\right)$ of the ground subsurface as

$\rho_{\mathrm{a}}=k \Delta V / l$.

During a tomographic resistivity survey, many of these measurements are made in lateral and vertical directions (by increasing the electrode spacing). The acquired data are subsequently modeled to generate an image of the resistivity distribution under the site. Values of resistivity vary substantially with grain size, porosity, water content, ice content, salinity, and temperature (e.g., Reynolds, 2011); thus, the resistivity of permafrost also varies to a large degree. This makes
ERT techniques useful in detecting the sharp contrast between frozen and unfrozen water content within sediments.

At the Tavvavuoma site, measurements of electrical resistivity were made with the Terrameter LS from ABEM and an electrode spacing of $2 \mathrm{~m}$ for the T1 transect and $4 \mathrm{~m}$ for the T2 and T3 transects. The Wenner array configuration for the electrodes was used due to its high signal-to-noise ratio and for its accuracy in detecting vertical changes over other common array types (Loke, 2010). For the inverse modeling, the smoothness-constrained least-square method was applied (Loke and Barker, 1996). The inversion progress was set to stop when the change in root mean squared error from the previous iteration was less than $5 \%$ (implying convergence of the inversion). The software Res2dinv (v.3.59.64, Geotomo Software, Loke, 2010) was used for the inverse modeling during this study.

To assess the quality and reliability of the resistivity modeling for the Tavvavuoma site, the depth of investigation (DOI) method (Oldenburg and Li, 1999) was used. This appraisal technique uses the difference between two inverted models where the reference resistivity parameter is varied to calculate a normalized DOI-index map. From these values a depth at which the surface data are no longer sensitive to the physical properties of the ground can be interpreted. The method has previously been applied in permafrost studies (e.g., Fortier et al., 2008; Marescot et al., 2003). To calculate the DOI-index we used a symmetrical two-sided dif- 
ference scheme where 0.1 and 10 times the average apparent resistivity of the resistivity model was considered (respectively) for the initial reference resistivity parameter. Normalized DOI values higher than 0.1 indicate that the model is likely not constrained by the data and should be given little significance in subsequent model interpretation.

To further validate the ERT interpretations, one shorter transect with $0.5 \mathrm{~m}$ electrode spacing was conducted over a palsa. This was used to acquire a local resistivity value for the interface between unfrozen and frozen sediments at the bottom of the active layer. This value $(1700 \Omega \mathrm{m})$ allowed us to map permafrost boundaries in the ERT images, with all resistivity values $>1700 \Omega \mathrm{m}$ interpreted as permafrost. However, as the resistivity of the ground varies with other sediment physical properties and the sediment distribution is complex at the site, the resistivity boundary value for permafrost will naturally vary along transects and with depth. For instance, sands generally have maximum values for the unfrozen state close to $1200 \Omega \mathrm{m}$ and for some gravels this can reach up to $3000 \Omega \mathrm{m}$ (Hoekstra et al., 1974). Finer sediments, such as clays and silts, have lower values ranging from ca. 80 to $300 \Omega \mathrm{m}$ (Hoekstra et al., 1974). At our site sands dominate, but there is also evidence of loams. Lewkowicz et al. (2011) report a resistivity of $1000 \Omega \mathrm{m}$ at the base of permafrost under a palsa in similar, but somewhat finer, sediment conditions in southern Yukon. This value from Lewkowicz et al. (2011) was thus used as a possible minimum resistivity value for the permafrost boundary in the interpretations, while the local resistivity estimate $(1700 \Omega \mathrm{m})$ was used as a maximum and representative value. All resistivity values $<1000 \Omega \mathrm{m}$ were thus interpreted as unfrozen ground and the values between 1000 and $1700 \Omega \mathrm{m}$ represent a range of uncertainty for the location of the interface between frozen and unfrozen sediments. Again, the motivation here was to account for potential uncertainty allowing for robust interpretation.

\subsection{Calculations of active layer thickness and future thaw rates}

To help put the geophysical measurements and their potential implications for this peatland palsa region in context, the thickness of the active layer as well as first-order estimate of long-term thaw rates were estimated using a simple equation for 1-D heat flow by conduction, the Stefan equation (as described by Riseborough et al., 2008):

$Z=\sqrt{\frac{2 \lambda I}{L n}}$,

where $Z$ is the thaw depth, $\lambda$ is thermal conductivity, $I$ is the thawing degree day index (as described by Nelson and Outcalt, 1987), $L$ is the volumetric latent heat of fusion, and $n$ is the saturated porosity of the ground substrate. As a talik is by definition unfrozen ground occurring in a permafrost area, Eq. (2) was used to confirm that ground identified as talik in Tavvavuoma through the GPR and ERT images did not correspond to locations of deeper active layer relative to surrounding positions (i.e., provide a confirmation that these sites would not freeze during winter).

Calculations of active layer depths in fens were made using a sinusoidal annual air temperature curve generated from the average temperature of the warmest and the coldest months of the year as input. The effect of the snow cover, which would give higher ground-surface temperatures in the winter, was not explicitly taken into consideration in this simple calculation as we did not have any direct estimates of snow cover available for the transects. As such, these calculations are simply a first-order approximation. Representative properties for saturated peat (the most common material in the uppermost part of the ground in suspected taliks) were chosen, including a thermal conductivity of $0.5 \mathrm{~W} \mathrm{~m}^{-1} \mathrm{~K}^{-1}$ and a saturated fraction of 0.80 (Woo, 2012).

In addition, a first-order approximation of long-term thaw rates was carried out. An instantaneous increase in air temperature of $2{ }^{\circ} \mathrm{C}$ was assumed, which represents a warming within current climate projections for the 21 st century, although at the low end of projections for Arctic warming (IPCC, 2013). Material properties for this calculation were based on information on deeper sediment layers from the $10 \mathrm{~m}$ borehole (Ivanova et al. 2011, point 1 in Fig. 1). A saturated fraction of 0.5 , representative of sand slightly oversaturated with ice, was used. To account for some of the uncertainty in this rough estimate, a range of likely minimum and maximum values for thermal conductivity ( 2 and $3 \mathrm{~W} \mathrm{~m}^{-1} \mathrm{~K}^{-1}$, respectively) for this material were used to estimate a range of thaw rates. The annual freezing degree days were subtracted from the annual thawing degree days, $I$ in Eq. (2), and the number of days necessary to thaw the estimated local thickness of permafrost was estimated. This is a simple estimate since, clearly, the Stefan equation is neither designed to calculate long-term thaw rates nor does such an estimate consider any density-dependent feedbacks and/or subsequent hydroclimatic shifts. Regardless, combined with estimates of permafrost thickness made in our geophysical investigation, the aim of this back-of-the-envelope calculation was to provide an order-of-magnitude estimate for the time it could potentially take permafrost to completely thaw at this site to help place it in a pan-arctic context.

\section{Results}

\subsection{GPR data}

In the GPR images the permafrost table was clearly detectable under the palsa and peat plateau surfaces along all transects (Fig. 4). The interface between peat and mineral substrates was only detectable in unfrozen sediments. Deeper reflections, interpreted as the permafrost table under suprapermafrost taliks, were found under the fens and surface 

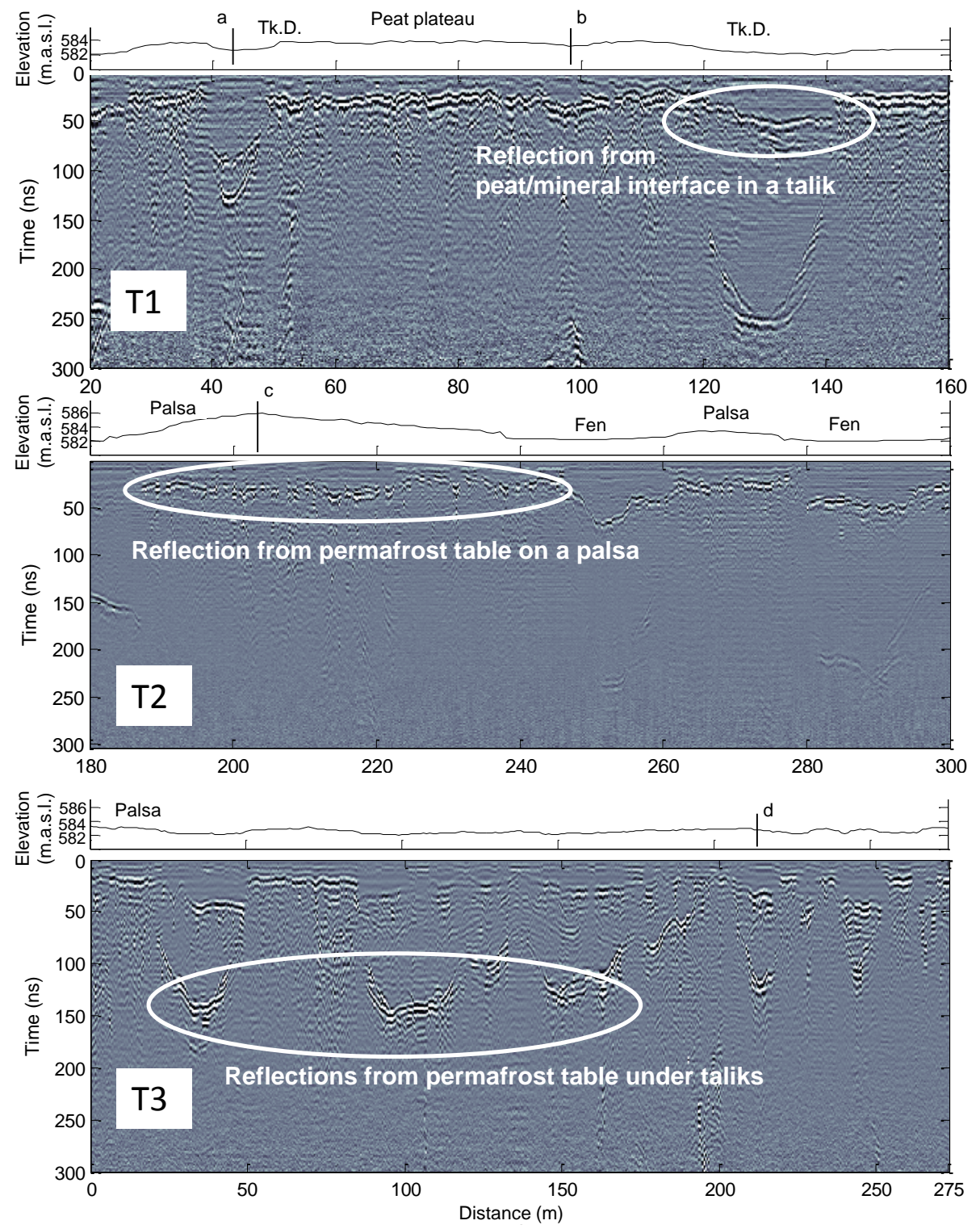

Figure 4. Elevation profiles and GPR images for T1, T2, and T3 with selected reflections marked as examples of interfaces that were identified for this study. Landforms are indicated on top of elevation profiles along T1 and T2 (Tk.D is thermokarst depression) together with coring points in $\mathrm{T} 1$ (a is point 3 in Fig. 1, and b is point 4 in Fig. 1) and T3 (d is point 6 in Fig. 1) as well as the $10 \mathrm{~m}$ borehole in T2 (c is point 1 in Fig. 1). No landforms are indicated along T3 after the first palsa $(0-25 \mathrm{~m})$ due to the complex micro topography of hummocks and thermokarst depressions along this transect.

depression in all transects. At the beginning of both transects $\mathrm{T} 1$ and $\mathrm{T} 2$, deep reflections that end abruptly were present in the images at about 250 and $150 \mathrm{~ns}$, respectively. In $\mathrm{T} 1$, this corresponds to a wet fen bordering a lake; for T2 it corresponds to a fen bordering a stream. The proximity to these water bodies suggests that these are likely not reflections from the permafrost table. The base of the permafrost could not be detected at any point in the GPR images likely because of loss of signal strength at depth.

\subsection{ERT data}

The inverted resistivity sections showed areas of high resistivity $(1000-100000 \Omega \mathrm{m})$ where permafrost could be expected due to the sharp contrast to surrounding surfaces. This suggests permafrost boundaries are detectable for both the extent of the horizontal distribution and the vertical extent to the base of permafrost (Fig. 5). The highest resistivity values were found under the peat plateau in T1 and under the palsas in $\mathrm{T} 2$ and $\mathrm{T} 3$. Low resistivity values were found under the fens in all transects. DOI values increase with depth for 


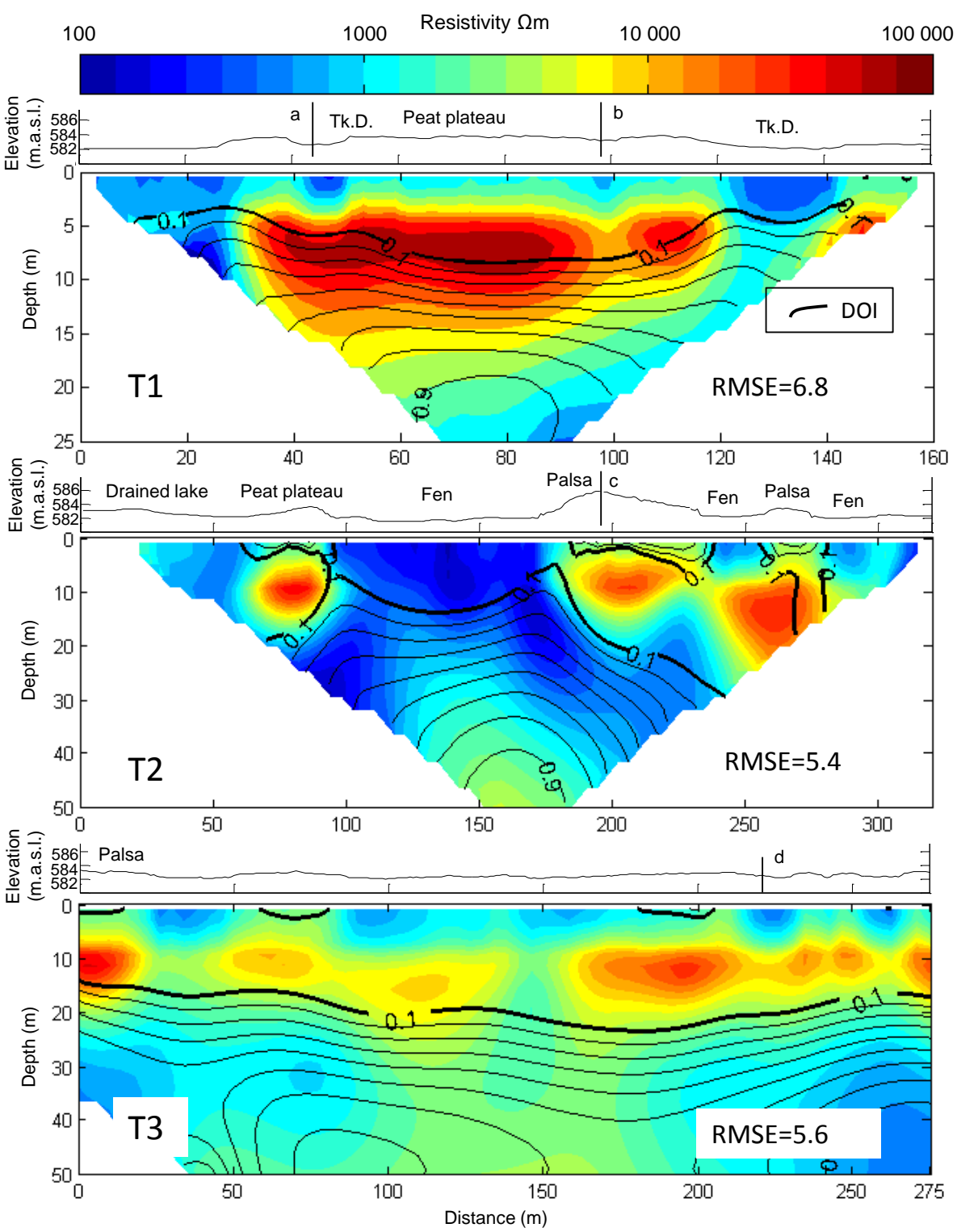

Figure 5. Elevation profiles and ERT results for T1, T2, and T3. DOI $<0.1$ (black lines) indicates that the model is well constrained by the data. Landforms are indicated on top of elevation profiles along T1 and T2 (Tk.D = thermokarst depression) together with coring points in $\mathrm{T} 1$ (a is point 3 in Fig. 1, and b is point 4 in Fig. 1) and T3 (d is point 6 in Fig. 1) as well as the $10 \mathrm{~m}$ borehole in T2 (c is point 1 in Fig. 1). No landforms are indicated along T3 after the first palsa $(0-25 \mathrm{~m})$ due to the complex micro topography of hummocks and thermokarst depressions along this transect.

all transects, allowing the permafrost base to be interpreted only along parts of $\mathrm{T} 2$. In contrast, under $\mathrm{T} 1$ and $\mathrm{T} 3$ the DOI rapidly increases under the peat plateau and hummocks. Due to the wide electrode spacing adopted ( 2 and $4 \mathrm{~m}$ ), the permafrost table under the active layer is too shallow to be visible in the ERT data.

\subsection{Geophysical interpretations}

Permafrost occurs under the palsa and peat plateau surfaces along T1 and T2 as well as under the hummocks along T3
(Fig. 6). The active layer depths estimated from the GPR data closely matched the depths measured in the field (Table 2). This is expected since measured active layer depths were used to derive the velocity of the radar signal in the dry peat in the active layer. The depth to the base of the permafrost could only be estimated with good confidence along parts of T2 and is on average $15.8 \mathrm{~m}$ from the ground surface and at least $25 \mathrm{~m}$ at its deepest point. Along transects T1 and T3 the deepest permafrost was found at 8.4 and $23.4 \mathrm{~m}$, respectively; however, the permafrost base could not be identified with confidence below this depth. 

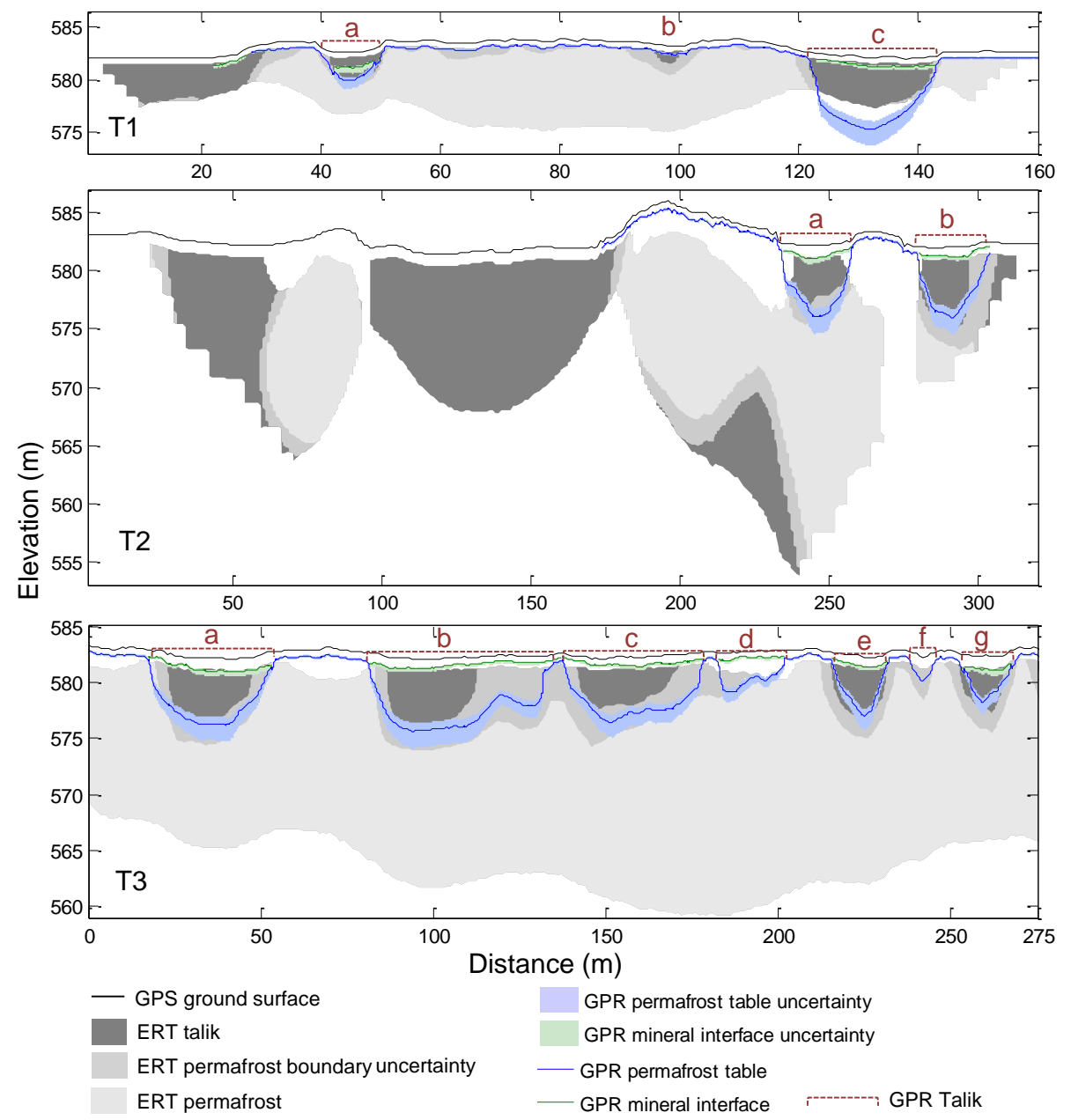

Figure 6. Interpreted permafrost distribution along T1, T2, and T3. Uncertainty intervals come from the range of estimated signal velocities for GPR (Table 1) and from the range of resistivity values (1000-1700 $\Omega \mathrm{m})$ used for identifying the permafrost boundary for ERT. In sections marked GPR Talik (red dotted line), GPR depth conversions have been made using saturated peat velocities down to the peat-mineral interface (green line) and then using saturated mineral substrate velocities down to the permafrost table (blue line). In the remaining parts of transects, the dry peat velocities have been used down to the permafrost table. No interpretations of ERT data with DOI $>0.1$ have been made and therefore the permafrost base is only visible along parts of T2. Note the differences in scale in the $x$ direction between figures and the vertical exaggeration.

Potential taliks (Table 3 and Fig. 6) are numerous and occur in both wet fens, such as all taliks along T2, and relatively dry depressions in the terrain, such as all taliks along T1. The sediment cores used for estimating the GPR representative signal velocity in saturated peat were taken in both a relatively dry location and a wet fen, but the calculated velocities were nearly identical, indicating that the soil moisture at depth was similar at both locations. Most of T3 was underlain by taliks and these were found under both wet fens and drier surface depressions. The taliks range in depth from $2.1 \mathrm{~m}$ (T3f, numbering from Table 3 and Fig. 6) to $6.7 \mathrm{~m}$ (T1c) based on the GPR data and are slightly deeper, although within the range of uncertainty based on the ERT results. From the ERT data, T1c is in fact interpreted as a potential through-going talik. Talik T1b was only detected from the ERT data, and taliks T3b-T3d appear as one large talik in the ERT data.

\subsection{Calculations of active layer thickness and future thaw rates}

The active layer depths calculated using the Stefan equation support the interpretation that identified taliks do not freeze during winter. The seasonal frost penetration depth was estimated to be $0.72 \mathrm{~m}$, which is about the same as the average peat depth along the transects and much less than the estimated minimum depth of the taliks $(2.1 \mathrm{~m})$. While a shallower peat depth would give a deeper frost penetration, it is unlikely that the seasonal frost penetration is $>2.1 \mathrm{~m}$ in the Tavvavuoma area. This ancillary estimate confirms 
Table 2. Range of interpreted depths (m) of active layer, peat-mineral interface, and permafrost base averaged along transects at Tavvavuoma.

\begin{tabular}{|c|c|c|c|c|c|c|c|c|c|}
\hline & \multicolumn{3}{|c|}{$\mathrm{T} 1$} & \multicolumn{3}{|c|}{$\mathrm{T} 2$} & \multicolumn{3}{|c|}{$\mathrm{T} 3$} \\
\hline & $\operatorname{Min}^{\mathrm{a}}$ & Representative $^{\mathrm{b}}$ & $\operatorname{Max}^{\mathrm{c}}$ & $\operatorname{Min}^{\mathrm{a}}$ & Representative $^{\mathrm{b}}$ & $\operatorname{Max}^{\mathrm{c}}$ & $\operatorname{Min}^{\mathrm{a}}$ & Representative $^{\mathrm{b}}$ & $\operatorname{Max}^{\mathrm{c}}$ \\
\hline \multicolumn{10}{|c|}{ Active layer } \\
\hline Observed $^{\mathrm{d}}$ & & 0.51 & & & 0.52 & & & 0.56 & \\
\hline GPR & 0.50 & 0.53 & 0.57 & 0.48 & 0.51 & 0.54 & 0.52 & 0.56 & 0.59 \\
\hline \multicolumn{10}{|c|}{ Peat-mineral interface } \\
\hline GPR & 0.77 & 0.84 & 1.14 & 0.68 & 0.74 & 1.01 & 0.63 & 0.69 & 0.93 \\
\hline \multicolumn{10}{|c|}{ Permafrost base } \\
\hline ERT & & - & - & & 15.8 & 17.3 & & - & - \\
\hline
\end{tabular}

Table 3. Estimated depths (m) of taliks at deepest point. Numbering is the same as in Fig. 6.

\begin{tabular}{|c|c|c|c|c|c|}
\hline Talik & $\begin{array}{l}\text { GPR } \\
\min ^{\mathrm{a}}\end{array}$ & $\begin{array}{c}\text { GPR } \\
\text { representative }^{b}\end{array}$ & $\begin{array}{l}\text { GPR } \\
\max ^{c}\end{array}$ & $\begin{array}{l}\text { ERT } \\
\min ^{\mathrm{a}}\end{array}$ & $\begin{array}{r}\text { ERT } \\
\text { representative }\end{array}$ \\
\hline T1a & 2.4 & 2.7 & 3.4 & 2.5 & 3.1 \\
\hline $\mathrm{T} 1 \mathrm{~b}$ & - & - & - & 1.6 & 2.8 \\
\hline T1c & 6.0 & 6.7 & 8.3 & $>4.7$ & $>4.7$ \\
\hline $\mathrm{T} 2 \mathrm{a}$ & 5.4 & 6.1 & 7.6 & 5.4 & 6.9 \\
\hline $\mathrm{T} 2 \mathrm{~b}$ & 5.3 & 6.0 & 7.4 & 6.9 & 8.8 \\
\hline T3a & 5.3 & 5.9 & 7.4 & 5.8 & 7.8 \\
\hline $\mathrm{T} 3 \mathrm{~b}$ & 5.7 & 6.4 & 8.0 & 6.3 & 8.2 \\
\hline T3c & 5.1 & 5.7 & 7.0 & 4.8 & 7.9 \\
\hline T3d & 3.1 & 3.5 & 4.4 & - & 4.0 \\
\hline T3e & 4.6 & 5.2 & 6.4 & 5.4 & 7.2 \\
\hline T3f & 2.0 & 2.1 & 2.2 & - & 3.8 \\
\hline $\mathrm{T} 3 \mathrm{~g}$ & 3.7 & 4.1 & 5.2 & 5.0 & 6.8 \\
\hline
\end{tabular}

the aforementioned geophysical interpretation. Furthermore, assuming a $2{ }^{\circ} \mathrm{C}$ instantaneous temperature increase at the site, a first-order approximation of the long-term thaw rate was calculated to be $6-8.5 \mathrm{~cm} \mathrm{yr}^{-1}$. At this rate, the time to completely thaw permafrost, assuming the estimated average thickness along T2 $(15.3 \mathrm{~m})$, was calculated to be $175-$ 260 years.

\section{Discussion}

\subsection{Permafrost and talik distribution at Tavvavuoma}

The spatial pattern of permafrost and taliks in Tavvavuoma is closely linked to the distribution of palsas, peat plateaus, fens, and water bodies. This suggests that local factors, such as soil moisture, groundwater flow, ground ice content, sediment distributions, and geomorphology, strongly influence the local ground thermal regime (see e.g., Delisle and Allard, 2003; McKenzie and Voss, 2013; Woo, 2012; Zuidhoff, 2002). The relative elevation of permafrost landforms, as well as permafrost resistivity values and sediment distributions, suggests that there is a large variation in ground ice content in the area. Surface elevations of palsas and peat plateaus are highest along T2 and lowest along T3, indicating a higher ice content of the underlying ground along T2, which is likely related to differences in ground substrates between the transects. Coring $(<2 \mathrm{~m})$ across the site and existing borehole descriptions (Ivanova et al., 2011) confirm that the ground contains a larger fraction of coarse glaciofluvial sand and gravel, which are not susceptible to frost heave, closer to $\mathrm{T} 3$ as compared to $\mathrm{T} 2$.

Lewkowicz et al. (2011) used the height of palsas and permafrost thickness, estimated by ERT, to calculate excess ice fractions (EIF, defined as the ratio of palsa height to permafrost thickness) in permafrost mounds in southern Yukon. In Tavvavuoma, the highest palsa at T2 is approximately $4 \mathrm{~m}$ high and underlain by $16 \mathrm{~m}$ thick permafrost at the highest point. This corresponds to an EIF of 0.25 , which is comparable to the EIFs reported by Lewkowicz et al. (2011) that generally ranged between 0.2 and 0.4 . In contrast, along T3 the relative heights of permafrost landforms are lower and the permafrost is thicker for most of the transect. Similarly calculated EIFs along T3 were on average $<0.03$ and at maximum $<0.09$ but are likely lower in reality as the base of the permafrost is at a greater depth than what could be detected in our study. The relatively low resistivity of the permafrost along T3 further supports interpretations for lower ice content in this permafrost. Permafrost with low ice content is more susceptible to thaw, as less energy is needed for latent heat exchange. This provides a possible explanation for why 
taliks are more widespread along $\mathrm{T} 3$, as permafrost with a low ice content would have reacted more rapidly to warming in the area.

The calculated thaw rate of $6-8.5 \mathrm{~cm} \mathrm{yr}^{-1}$ is considerably higher than the ca. $1 \mathrm{~cm} \mathrm{yr}^{-1}$ deepening of the active layer observed in the region (Åkerman and Johansson, 2008) and inferred from hydrological records (Lyon et al., 2009). One possible reason for this is that these observations were made in the relatively ice-rich top layer of peat, while for the calculations in this study a medium with higher thermal conductivity and lower ice content was used to represent the lower mineral sediment layer. The $2{ }^{\circ} \mathrm{C}$ instantaneous step change in temperature could have further contributed to the higher thaw rates compared to the ones observed. As thawing is driven by gradients in heat it can be argued that permafrost thaw rates should increase with warmer air temperatures. Considering this, the calculated time of complete permafrost thaw of about 175-260 years can be considered reasonable in at least 1 order of magnitude. However, much more rapid palsa degradation has been observed in the region (Zuidhoff, 2002) due to block and wind erosion processes and thermal influence on palsas from expanding water bodies, and very rapid decay of palsa surface areas has been observed in both southern Norway and the Canadian Arctic (Payette et al., 2004; Sollid and Sorbel, 1998). The coupled erosion, hydrological, and thermal processes are not represented in the Stefan equation but can be of great importance for permafrost thaw rates (McKenzie and Voss, 2013; Painter et al., 2013; Zuidhoff, 2002). There is clearly a need for quantification of the relative importance of these processes for permafrost thaw to better understand expected future changes in these environments.

\subsection{On the complementary nature of the geophysical techniques}

Several previous studies have shown the benefits of combining more than one geophysical technique for mapping permafrost (e.g., De Pascale et al., 2008; Hauck et al., 2004; Schwamborn et al., 2002); in this study the GPR and ERT data also provided complementary information that allowed for interpretations that would not have been possible by using only one of the two data sets. Of course, combining multiple techniques for inference compounds our estimate uncertainties. To attain more precise estimates of depths to the different interfaces, deeper coring data would have been necessary for both more accurate signal velocity estimates for the GPR and for local resistivity values of the ground materials. The fact that ERT depth estimates are consistently higher than the GPR estimates suggest that either the resistivity boundary value for permafrost is in fact lower than our local estimate, or that GPR signal velocities are higher than the values used in this study. Since our local permafrost resistivity estimate was made in peat at the permafrost table, which can have a very high ice content compared to deeper sediment layers, it is a more likely explanation for this discrepancy.

GPR and ERT yielded somewhat overlapping data but the two data sets have different strengths and therefore complement each other well. The GPR data worked well for identifying the permafrost table with high confidence, especially in the top $2 \mathrm{~m}$ where sediment cores could be easily obtained for validation and signal velocity estimates. This suitability of GPR for identifying permafrost interfaces in the top 1$2 \mathrm{~m}$ has been shown in several studies (e.g., Doolittle et al., 1992; Hinkel et al., 2001; Moorman et al., 2003). The ERT data, using the setup in this study, do not yield data in the uppermost part of the ground and also have higher uncertainty where resistivity contrasts are high (Fig. 5), which makes them less suited for the active layer and shallow taliks. With the ERT data it is, however, possible to image relatively deep in the ground where the GPR cannot penetrate. By combining both GPR and ERT the active layer, the base of permafrost, and potential taliks could be identified along at least parts of the transects, which could not have been achieved with good confidence by either of the two methods alone.

\section{Concluding remarks}

Peat plateau complexes offer an interesting challenge to the Cryosphere community as they are clear mosaics combining local-scale differences manifested as permafrost variations. As such variation occurs both horizontally and vertically in the landscape, geophysical techniques offer a good possibility to record current permafrost conditions across scales. Furthermore, by combining methods, such as GPR and ERT as demonstrated here, complementary and independent views of the permafrost extents can be acquired. The results of this study show a heterogeneous pattern of permafrost extent reflecting both local and climatic processes of permafrost formation and degradation. To improve our understanding of landscape-permafrost interactions and dynamics will require a community effort to benchmark variability across the scales and environments within the pan-Arctic. This is particularly important in lesser-studied regions and across the sporadic permafrost zone where changes are occurring rapidly.

Author contributions. Ylva Sjöberg designed the study, carried out the GPR measurements and analysis, and did the main writing of the manuscript. Per Marklund carried out the ERT measurements and analysis, did the main writing for the sections on ERT methods and ERT results, and commented on the whole manuscript. Rickard Pettersson provided input on the geophysical techniques and analyses and commented on the whole manuscript. Steve Lyon provided input on the project design and commented on the whole manuscript, including language and style. 
Acknowledgements. This study was kindly supported by Sveriges Geologiska Undersökning (SGU), the Bolin Centre for Climate Research, Lagrelius fond, Göran Gustafssons Stiftelse för natur och miljö i Lappland, and Svenska Sällskapet för Antropologi och Geografi. The authors are grateful to Peter Jansson and Britta Sannel for lending us the equipment necessary for this study and to Romain Pannetier, Kilian Krüger, Matthias Siewert, Britta Sannel, and Lars Labba for fieldwork support. We are also grateful to Andrew Parsekian for technical advice on the GPR survey design and María A. García Juanatey for consultation when processing the ERT data.

Edited by: J. Boike

\section{References}

Åkerman, H. J. and Johansson, M.: Thawing permafrost and thicker active layers in sub-arctic Sweden, Permafrost Periglac., 19, 279-292, doi:10.1002/ppp.626, 2008.

Alexandersson, H.: Temperature and precipitation in Sweden 18602001, SMHI, Norrköping, Sweden, 2002.

Arcone, S. A., Lawson, D. E., Delaney, A. J., Strasser, J. C., and Strasser, J. D.: Ground-penetrating radar reflection profiling of groundwater and bedrock in an area of discontinuous permafrost, Geophysics, 63, 1573-1584, doi:10.1190/1.1444454, 1998.

Christiansen, H. H., Etzelmuller, B., Isaksen, K., Juliussen, H., Farbrot, H., Humlum, O., Johansson, M., Ingeman-Nielsen, T., Kristensen, L., Hjort, J., Holmlund, P., Sannel, A. B. K., Sigsgaard, C., Akerman, H. J., Foged, N., Blikra, L. H., Pernosky, M. A., and Odegard, R. S.: The Thermal State of Permafrost in the Nordic Area during the International Polar Year 2007-2009, Permafrost Periglac., 21, 156-181, doi:10.1002/ppp.687, 2010.

Davis, J. L. and Annan, A. P.: Ground-penetrating radar for highresolution mapping of soil and rock, Geophys. Prospect., 37, 531-551, doi:10.1111/j.1365-2478.1989.tb02221.x, 1989.

Delisle, G. and Allard, M.: Numerical simulation of the temperature field of a palsa reveals strong influence of convective heat transport by groundwater, in: Proceeding of the 8th International Permafrost Conference, 21-25 July 2003, Zurich, Switzerland, 181-186, 2003.

De Pascale, G. P., Pollard, W. H., and Williams, K. K.: Geophysical mapping of ground ice using a combination of capacitive coupled resistivity and ground-penetrating radar, Northwest Territories, Canada, J. Geophys. Res.-Earth., 113, F02S90, doi:10.1029/2006jf000585, 2008.

Dobinski, W.: Geophysical characteristics of permafrost in the Abisko area, northern Sweden, Pol. Polar Res., 31, 141-158, doi:10.4202/ppres.2010.08, 2010.

Doolittle, J. A., Hardisky, M. A., and Black, S.: A groundpenetrating radar study of Goodstream palsas, Newfoundland, Canada, Arct. Alp. Res., 24, 173-178, doi:10.2307/1551537, 1992.

Fortier, R., LeBlanc, A. M., Allard, M., Buteau, S., and Calmels, F.: Internal structure and conditions of permafrost mounds at Umiujaq in Nunavik, Canada, inferred from field investigation and electrical resistivity tomography, Can. J. Earth Sci., 45, 367-387, doi:10.1139/e08-004, 2008.
Gacitua, G., Tamstorf, M. P., Kristiansen, S. M., and Uribe, J. A.: Estimations of moisture content in the active layer in an Arctic ecosystem by using ground-penetrating radar profiling, J. Appl. Geophys., 79, 100-106, doi:10.1016/j.jappgeo.2011.12.003, 2012.

Giesler, R., Lyon, S. W., Mörth, C.-M., Karlsson, J., Karlsson, E. M., Jantze, E. J., Destouni, G., and Humborg, C.: Catchmentscale dissolved carbon concentrations and export estimates across six subarctic streams in northern Sweden, Biogeosciences, 11, 525-537, doi:10.5194/bg-11-525-2014, 2014.

Hauck, C., Vonder Muhll, D., and Maurer, H.: Using DC resistivity tomography to detect and characterize mountain permafrost, Geophys. Prospect., 51, 273-284, doi:10.1046/j.13652478.2003.00375.x, 2003.

Hauck, C., Isaksen, K., Muhll, D. V., and Sollid, J. L.: Geophysical surveys designed to delineate the altitudinal limit of mountain permafrost: An example from Jotunheimen, Norway, Permafrost Periglac., 15, 191-205, doi:10.1002/ppp.493, 2004.

Hinkel, K. M., Doolittle, J. A., Bockheim, J. G., Nelson, F. E., Paetzold, R., Kimble, J. M., and Travis, R.: Detection of subsurface permafrost features with ground-penetrating radar, Barrow, Alaska, Permafrost Periglac., 12, 179-190, doi:10.1002/ppp.369, 2001.

Hoekstra, P., Selimann, P., and Delaney, A.: Airborne resistivity mapping of permafrost near Fairbanks, Alaska, US Army CRREL, Hanover, New Hampshire, 51, 1974.

Hugelius, G., Bockheim, J. G., Camill, P., Elberling, B., Grosse, G., Harden, J. W., Johnson, K., Jorgenson, T., Koven, C. D., Kuhry, P., Michaelson, G., Mishra, U., Palmtag, J., Ping, C.-L., O’Donnell, J., Schirrmeister, L., Schuur, E. A. G., Sheng, Y., Smith, L. C., Strauss, J., and Yu, Z.: A new data set for estimating organic carbon storage to $3 \mathrm{~m}$ depth in soils of the northern circumpolar permafrost region, Earth Syst. Sci. Data, 5, 393-402, doi:10.5194/essd-5-393-2013, 2013.

Hugelius, G., Strauss, J., Zubrzycki, S., Harden, J. W., Schuur, E. A. G., Ping, C.-L., Schirrmeister, L., Grosse, G., Michaelson, G. J., Koven, C. D., O’Donnell, J. A., Elberling, B., Mishra, U., Camill, P., Yu, Z., Palmtag, J., and Kuhry, P.: Estimated stocks of circumpolar permafrost carbon with quantified uncertainty ranges and identified data gaps, Biogeosciences, 11, 6573-6593, doi:10.5194/bg-11-6573-2014, 2014.

IPCC: Climate Change 2013: The Physical Science Basis, in: Contribution of Working Group I to the Fifth Assessment Report of the Intergovernmental Panel on Climate Change, edited by: Stocker, T. F., Qin, D., Plattner, G.-K., Tignor, M., Allen, S. K., Boschung, J., Nauels, A., Xia, Y., Bex, V., and Midgley, P. M., Cambridge University Press, Cambridge, UK and New York, NY, USA, 1535 pp., 2013.

Ishikawa, M., Watanabe, T., and Nakamura, N.: Genetic differences of rock glaciers and the discontinuous mountain permafrost zone in Kanchanjunga Himal, eastern Nepal, Permafrost Periglac., 12, 243-253, doi:10.1002/ppp.394, 2001.

Ivanova, N. V., Kuznetsova, I. L., Parmuzin, I. S., Rivkin, F. M., and Sorokovikov, V. A.: Geocryological Conditions in Swedish Lapland, in: Proceedings of the 4th Russian Conference on Geocryology, 7-9 June 2011, Moscow State University, Moscow, Russia, 77-82, 2011.

Jantze, E. J., Lyon, S. W., and Destouni, G.: Subsurface release and transport of dissolved carbon in a discontinuous permafrost re- 
gion, Hydrol. Earth Syst. Sci., 17, 3827-3839, doi:10.5194/hess17-3827-2013, 2013.

Joseph, S., Giménez, D., and Hoffman, J. L.: Dielectric permittivity as a function of water content for selected New Jersey soils, New Jersey Geological and Water Survey, Trenton, NJ, available at: http://www.state.nj.us/dep/njgs/geodata/dgs10-1.htm (last access: 17 December 2013), 2010.

Klingbjer, P. and Moberg, A.: A composite monthly temperature record from Tornedalen in northern Sweden, 1802-2002, Int. J. Climatol., 23, 1465-1494, doi:10.1002/joc.946, 2003.

Kneisel, C., Hauck, C., and Vonder Muhll, D.: Permafrost below the timberline confirmed and characterized by geoelectrical resistivity measurements, Bever Valley, eastern Swiss Alps, Permafrost Periglac., 11, 295-304, doi:10.1002/10991530(200012)11:4<295::aid-ppp353>3.0.co;2-1, 2000.

Kneisel, C., Saemundsson, D., and Beylich, A. A.: Reconnaissance surveys of contemporary permafrost environments in central Iceland using geoelectrical methods: Implications for permafrost degradation and sediment fluxes, Geogr. Ann. A, 89, 41-50, doi:10.1111/j.1468-0459.2007.00306.x, 2007.

Kneisel, C., Emmert, A., and Kästl, J.: Application of 3D electrical resistivity imaging for mapping frozen ground conditions exemplified by three case studies, Geomorphology, 210, 71-82, doi:10.1016/j.geomorph.2013.12.022, 2014.

Lewkowicz, A. G., Etzelmuller, B., and Smith, S. L.: Characteristics of Discontinuous Permafrost based on Ground Temperature Measurements and Electrical Resistivity Tomography, Southern Yukon, Canada, Permafrost Periglac., 22, 320-342, doi:10.1002/ppp.703, 2011.

Loke, M. H.: Rapid 2-D Resistivity \& IP inversion using the leastsquares method (RES2DINV ver. 3.59 for Windows XP/Vista/7, manual), Geotomo Software, Malaysia, 2010.

Loke, M. H. and Barker, R. D.: Rapid least-squares inversion of apparent resistivity pseudosections by a quasi-Newton method, Geophys. Prospect., 44, 131-152, doi:10.1111/j.13652478.1996.tb00142.x, 1996.

Lyon, S. W., Destouni, G., Giesler, R., Humborg, C., Mörth, M., Seibert, J., Karlsson, J., and Troch, P. A.: Estimation of permafrost thawing rates in a sub-arctic catchment using recession flow analysis, Hydrol. Earth Syst. Sci., 13, 595-604, doi:10.5194/hess-13-595-2009, 2009.

Lyon, S. W., Mörth, M., Humborg, C., Giesler, R., and Destouni, G.: The relationship between subsurface hydrology and dissolved carbon fluxes for a sub-arctic catchment, Hydrol. Earth Syst. Sci., 14, 941-950, doi:10.5194/hess-14-941-2010, 2010.

Marescot, L., Loke, M. H., Chapellier, D., Delaloye, R., Lambiel, C., and Reynard, E.: Assessing reliability of 2D resistivity imaging in mountain permafrost studies using the depth of investigation index method, Near Surf. Geophys., 1, 57-67, 2003.

McKenzie, J. M. and Voss, C. I.: Permafrost thaw in a nested groundwater-flow system, Hydrogeol. J., 21, 299-316, doi:10.1007/s10040-012-0942-3, 2013.

Moorman, B. J., Robinson, S. D., and Burgess, M. M.: Imaging periglacial conditions with ground-penetrating radar, Permafrost Periglac., 14, 319-329, doi:10.1002/ppp.463, 2003.

Neidell, N. S. and Taner, T. M.: Semblance and other coherency measures for multichannel data, Geophysics, 36, 482-497, 1971.
Nelson, F. E. and Outcalt, S. I.: A computational method for prediction and regionalization of permafrost, Arct. Alp. Res., 19, 279-288, doi:10.2307/1551363, 1987.

Oldenburg, D. W. and Li, Y. G.: Estimating depth of investigation in dc resistivity and IP surveys, Geophysics, 64, 403-416, doi:10.1190/1.1444545, 1999.

Painter, S. L., Moulton, J. D., and Wilson, C. J.: Modeling challenges for predicting hydrologic response to degrading permafrost, Hydrogeol. J., 21, 221-224, doi:10.1007/s10040-0120917-4, 2013.

Payette, S., Delwaide, A., Caccianiga, M., and Beauchemin, M.: Accelerated thawing of subarctic peatland permafrost over the last 50 years, Geophys. Res. Lett., 31, L18208, doi:10.1029/2004g1020358, 2004.

Reynolds, J. M.: An Introduction to Applied and Environmental Geophysics, 2nd Edn., John Wiley \& Sons, Hoboken, 2011.

Riseborough, D., Shiklomanov, N., Etzelmuller, B., Gruber, S., and Marchenko, S.: Recent advances in permafrost modelling, Permafrost Periglac., 19, 137-156, doi:10.1002/ppp.615, 2008.

Sandmeier Geophysical Research: ReflexW software version 6.1, available at: http://www.sandmeier-geo.de (last access: March 2015), 2012.

Sannel, A. B. K. and Kuhry, P.: Warming-induced destabilization of peat plateau/thermokarst lake complexes, J.Geophys. Res.Biogeo., 116, 156-181, doi:10.1029/2010jg001635, 2011.

Schwamborn, G. J., Dix, J. K., Bull, J. M., and Rachold, V.: High-resolution seismic and ground penetrating radargeophysical profiling of a thermokarst lake in the western Lena Delta, northern Siberia, Permafrost Periglac., 13, 259-269, doi:10.1002/ppp.430, 2002.

Seppälä, M.: Synthesis of studies of palsa formation underlining the importance of local environmental and physical characteristics, Quatern. Res., 75, 366-370, doi:10.1016/j.yqres.2010.09.007, 2011.

Sjöberg, Y., Frampton, A., and Lyon, S. W.: Using streamflow characteristics to explore permafrost thawing in northern Swedish catchments, Hydrogeol. J., 21, 121-131, doi:10.1007/s10040012-0932-5, 2013.

Sollid, J. L. and Sorbel, L.: Palsa bogs as a climate indicator - Examples from Dovrefjell, southern Norway, Ambio, 27, 287-291, 1998.

Tarnocai, C., Canadell, J., Mazhitova, G., Schuur, E. A. G., Kuhry, P., and Zimov, S.: Soil organic carbon stocks in the northern circumpolar permafrost region, Global Biogeochem. Cy., 23, GB2023, doi:10.1029/2008GB003327, 2009.

Westermann, S., Wollschläger, U., and Boike, J.: Monitoring of active layer dynamics at a permafrost site on Svalbard using multichannel ground-penetrating radar, The Cryosphere, 4, 475-487, doi:10.5194/tc-4-475-2010, 2010.

Woo, M.-K.: Permafrost Hydrology, Springer, Heidelberg, 563 pp., 2012.

Wramner, P.: Studier av palsmyrar i Tavvavuoma och Laivadalen, Lappland - Studies of palsa mires in Tavvavuoma and Laivadalen, Lappland, Licenciate Thesis, Göteborg University, Gothenburg, Sweden, 1968.

Wramner, P.: Palsmyrar i Tavvavuoma, Lappland (Palsa mires in Tavvavuoma, Lapland), GUNI report 3, Göteborg University, Gothenburg, Sweden, 1973. 
Wramner, P., Backe, S., Wester, K., Hedvall, T., Gunnarsson, U., Alsam, S., and Eide, W.: Förslag till övervakningsprogram för Sveriges palsmyrar - Proposed monitoring program for Sweden's palsa mires, Länsstyrelsen i Norrbottens Län, Luleå, Sweden, 2012.

Zuidhoff, F. S.: Recent decay of a single palsa in relation to weather conditions between 1996 and 2000 in Laivadalen, northern Sweden, Geogr. Ann. A, 84, 103-111, doi:10.1111/14680459.00164, 2002.
Zuidhoff, F. S. and Kolstrup, E.: Changes in palsa distribution in relation to climate change in Laivadalen, northern Sweden, especially 1960-1997, Permafrost Periglac., 11, 55-69, doi:10.1002/(sici)1099-1530(200001/03)11:1<55::aidppp338>3.0.co;2-t, 2000. 